\title{
Analisis Pengaruh Pendapatan dan Pengetahuan Terhadap Minat Calon Nasabah Berinvestasi Emas di Pegadaian Syariah
}

\author{
Juli Dwina Puspita Sari* , Sayyidah Azzafira** \\ Fakultas Ekonomi dan Bisnis Islam IAIN Langsa, \\ *julidwina@iainlangsa.ac.id \\ **Sayyidah@gmail.com
}

\begin{abstract}
Abstrak
Penelitian ini dilakukan untuk menguji Pengaruh Pendapatan dan Pengetahuan Terhadap Minat Calon Nasabah Berinvestasi Emas di Pegadaian Syariah. Adapun teknik pengambilan sampel pada penelitian ini dilakukan melalui probability sampling dengan simple random sampling sebanyak 99 nasabah yang belum berinvestasi emas di pegadaian syariah kota langsa. Metode yang digunakan adalah analisis regresi berganda dan uji hipotesis menggunakan t-statistik untuk menguji koefisien bersama-sama dengan level of significance $5 \%$. Selain itu juga dilakukan uji asumsi klasik yang meliputi uji normalitas, uji multikolinearitas, uji heterokedastisitas dan uji autokorelasi. Hasil penelitian menunjukkan bahwa data penelitian berdistribusi normal dan tidak ditemukan variabel yang menyimpang dari asumsi klasik, yang berarti bahwa data yang tersedia telah memenuhi syarat untuk menggunakan model persamaan regresi berganda. Secara parsial variabel pendapatan, pengetahuan berpengaruh positif dan signifikan (dengan nilai signifikasinya $0,000<0,05)$ terhadap minat calon nasabah berinvestasi emas di Pegadaian Syariah Kota Langsa.Sedangkan secara simultan variabel pendapatan dan variabel pengetahuan berpengaruh positif dan signifikan (dengan nilai signifikasinya $0,000<0,05)$ terhadap minat calon nasabah berinvestasi emas di Pegadaian Syariah Kota Langsa.
\end{abstract}

Kata Kunci: pengetahuan, pendapatan, minat, investasi emas, pegadaian syariah.

\begin{abstract}
This study was conducted to examine the effect of income and knowledge on the interest of prospective customers to invest in gold in Pegadaian Syariah. The sampling technique in this study was carried out through probability sampling with simple random sampling. 99 customers who had not invested in gold in thePegadaian Syariah is definded as the respondents. The method used is multiple regression analysis and hypothesis testing using t-statistics to test the coefficients together with a level of significance of 5\%. In addition, the classical assumption test was also carried out which included normality test, multicollinearity test, heteroscedasticity test and autocorrelation test. The results showed that the research data were normally distributed and there were no variables that deviated from the classical assumptions,
\end{abstract}


which also means that the available data has met the requirements to use the multiple regression equation model. Partially, the income and knowledge variable have a positive and significant effect (with a significance value of $0.000<0.05$ ) on the interest of prospective customers to invest in gold in Pegadaian Syaria Located in Langsa. Meanwhile, simultaneously the income and the knowledge variable have a positive and significant effect (with a significance value of $0.000<0.05$ ) on the interest of prospective customers to invest in gold Pegadaian Syaria Located in Langsa.

Keywords :knowledge, income, interest, gold investment, Pegadaian Syariah

\section{PENDAHULUAN}

Islam telah mengatur suatu mekanisme dalam pengembangan harta, serta menjelaskan hukum - hukum yang harus dipatuhi atau yang dilarang untuk dikerjakan dan salah satu usaha untuk pengembangan harta dan kekayaan adalah melalui kegiatan investasi (Hayati, 2016). Investasi merupakan penanaman dana atau penetapan aset dengan maksud untuk memperoleh keuntungan dikemudian hari. Berinvestasi merupakan salah satu cara menyimpan uang atau aset yang dilakukan oleh banyak orang untuk memenuhi kebutuhan dimasa yang akan datang (Karim, 2016).

Beberapa jenis investasi dapat berupa uang, saham, properti dan juga emas. Salah satu lembaga keuangan non bank yang menawarkan jasa investasi dalam bentuk emas adalah Pegadaian Syariah. Investasi emas bertujuan untuk mengamankan kekayaan, mempertahankan nilai beli di masa depan, mencukupi rencana masa depan, dan bisa juga untuk menambah kekayaan (Bakri, 2016).

Dalam Islam terdapat hukum untuk melakukan investasi emas yang halal. MUI memutuskan hukum menabung emas masuk kategori mubah yang bermakna boleh untuk dilakukan (Dewan Syariah Nasional, 2021). Majelis Ulama Indonesia (MUI) melalui Dewan Syariah Nasional keluarkan fatwa No. 77/DSN-MUI/V/2010 tentang Jual Beli Emas Secara Tidak Tunai. Fatwa tersebut menyatakan "Jual beli emas secara tidak tunai, baik melalui jual beli biasa atau jual beli murabahah, hukumnya boleh (mubah/ja'iz) selama emas tidak menjadi alat tukar yang resmi (uang)"( Sahroni\& Yahya, 2021).

Minat adalah suatu hal yang bersumber dari perasaan yang berupa kecenderungan terhadap suatu hal sehingga menimbulkan perbuatan-perbuatan atau kegiatan-kegiatan tertentu. Minat merupakan daya tarik nasabah yang mempunyai keinginan untuk melakukan kegiatan tertentu (Syarif\&Asroi, 2013). Oleh karena itu, minat merupakan hal yang sangat penting yang harus diperhatikan dalam meningkatkan jumlah nasabah di suatu lembaga keuangan baik bank maupun non bank, termasuk Kantor Cabang 
Pegadaian Syariah Kota Langsa.

Pengetahuan masyarakat berperan penting dalam menarik minat masyarakat untuk berinvestasi dalam bentuk tabungan emas. Hal ini dikarenakan pengetahuan diperlukan sebagai bahan pertimbangan dalam memilih produk tabungan emas yang ditawarkan oleh pe1gadaian syariah. Pengetahuan seseorang dapat diperoleh melalui informasi yang di berikan oleh pegadaian syariah melalui media seperti media cetak, media sosial, pamflet, dan bisa juga melalui pengalaman seseorang, tujuannya adalah untuk menarik minat calon nasabah dalam melakukan investasi emas di Pegadaian Syariah cabang Kota Langsa.

Pendapatan tidak kalah penting untuk menarik minat calon nasabah, karena pendapatan bisa mempengaruhi minat calon nasabah terhadap investasi emas. Semakin tinggi pendapatan seseorang maka akan semakin tinggi daya beli seseorang, begitu juga sebaliknya. Pendapatan merupakan modal bagi calon nasabah untuk melakukan investasi emas, dengan memiliki modal maka akan timbul minat untuk berinvestasi emas.

\section{Pengertian Pegadaian Syariah}

Pegadaian Syariah merupakan suatu organisasi yang bergerak dalam bidang pelayanan jasa peminjaman uang dengan menggadaikan suatu barang yang bernilai sebagai jaminannya dengan menerapkan prinsip-prinsip syariah. Secara sederhana gadai adalah semacam jaminan hutang (Puspitasari, 2018). Dalam menjalankan pegadaian syariah, pegadaian harus menjalankan rukun gadai syariah. Rukun gadai syariah antara lain (Sutedi, 2011):

1. Ar-Rahin (yang menggadaikan)

Orang yang telah dewasa, berakal, bisa dipercaya, dan memilki barang yang digadaikan.

2. Al-Murtahin (yang menerima gadai)

Orang, bank, atau lembaga yang dipercaya oleh rahin untuk mendapatkan modal dengan jaminan barang (gadai).

3. Al-Marhun/Rahn (barang yang digadaikan)

Barang yang digunakan rahin untuk dijadikan jaminan dalam mendapatkan hutang.

4. Al-Marhun Bih (hutang)

Sejumlah dana yang diberikan murtahin kepada rahin atas dasar besarnya tafsiran marhun. 
5. Shighat, ijab dan qabul

\section{Produk-produkPegadaian Syariah}

Pegadaian Syariah merupakan unit usaha dari PT Pegadaian, salah satu lembaga keuangan milik pemerintah. Unit bisnis ini tidak hanya menyediakan produk berbasis gadai, melainkan memberikan layanan pembiayaan lain dengan prinsip Syariah (Ulfa $\mathrm{KN}, 2019$ ). Beberapa produk gadai syariah mengalami inovasi terbaru sesuai dengan perkembangan zaman antara lain adalah sebagai berikut (Ulfa KN, 2019):

1. Arrum Haji

2. Arrum BPKB (Buku Pemilik Kendaraan Bermotor)

3. Amanah

4. Rahn (Gadai Syariah)

5. Konsinyasi Emas

6. Tabungan Emas

7. Mulia

\section{Pendapatan}

Pendapatan adalah jumlah pendapatan atau penghasilan yang diterima oleh masyarakat untuk jangka waktu tertentu sebagai balas jasa atas faktor-faktor produksi yang mereka sumbangkan dalam turut serta membentuk produk nasional (Moena, 2016). Pendapatan sangat berperan aktif bagi suatu usaha, semakin besar pendapatan yang diperoleh maka semakin besar kemampuan suatu usaha untuk membiayai segala pengeluaran dan kegiatan-kegiatan yang akan dilakukan. Adapun indikator yang digunakan dalam penelitian ini adalah:

1. Pendapatan penghasilan tetap

2. Pendapatan penghasilan tidak tetap

3. Pendapatan dari usaha lain

\section{Pengetahuan}

Menurut Kamus Besar Bahasa Indonesia (KBBI), pengetahuan adalah segala sesuatu yang diketahui. Faktor-faktor yang mempengaruhi pengetahuan antara lain :

1. Faktor Internal : a) Pengalaman, b) Minat, c) Usia

2. FaktorExternal :a. Ekonomi, b. Informasi,c. Kebudayaan/Lingkungan 
Adapun indikator dalam penelitian ini adalah:

1. Pengetahuan terhadap produk

2. Pengetahuan terhadap prosedur

3. Pengetahuan terhadap syarat investasi emas

\section{Minat}

Minat merupakan suatu keinginan yang cenderung menetap pada diri seseorang untuk mengarahkan pada suatu pilihan tertentu sebagai kebutuhannya, kemudian dilanjutkan untuk diwujudkan dalam tindakan nyata dengan adanya perhatian pada objek yang diinginkan yaitu untuk mencari informasi sebagai wawasan bagi dirinya (Rahmadi \& Heryanto, 2016).

Faktor-faktor yang mempengaruhi minat yaitu sebagai berikut (Adisasmito, 2015):

a. Dorongan dari dalam individu :dorongan untuk makan. Dorongan untuk makanaan membangkitkan minat untuk bekerja atau mencari penghasilan, minat terhadap produksi makanan dan lain-lain.

b. Motif sosial : Dapat menjadi faktor yang membangkitkan minat untuk melakukan suatu aktivitas tertentu. Perilaku konsumen dalam membeli produk mulai berubah, konsumen tidak percaya begitu saja dengan promosi dan iklan, pegambilan keputusan konsumen sudah sangat sosial, artinya konsumen mencari rekomendasi dan testimony dan konsumen lain, khususnya di komunitas.

c. Faktor emosional: Minat mempunyai hubungan yang erat dengan emosi. Dengan demikian maka dapat dikatakan bahwa minat adalah dorongan kuat bagi seseorang untuk melakukan segala sesuatu dalam mewujudkan pencapaian tujuan dan cita-cita yang menjadi keinginannya.

Adapun indikator yang digunakan oleh penulis dalam penelitian ini adalah:

1. Minat Transaksional

2. Minat Referensial

3. Minat Preferensial

4. Minat Eksploratif

\section{Investasi dalam Islam}

Investasi dalam Islam dapat digambarkan sebagai suatu kegiatan produktif yang menguntungkan bila dilihat dari sudut pandang teologis, dan menjadi untung-rugi bila dipandang dari sisi ekonomi. Artinya karena dalam hidup ada sebuah ketidakpastian, 
maka apa yang dilakukan/diusahakan manusia baik dengan organisasi perdagangan atau tidak, di samping ada faktor lain, maka keuntungan dan kerugian bisa saja menghampirinya, dan yang menjadi kelebihan investasi dalam Islam adalah semua aktivitas dan kegiatan yang dilakukan oleh manusia harus sesuai dengan kaidah-kaidah syariah yang sejalur dengan al-Quran dan al-Hadits (Aziz, 2010). Dalam al-Quran terdapat beberapa ayat-ayat yang secara tidak langsung telah memerintahkan kaum muslimin untuk mempersiapkan hari esok secara lebih baik. Ayat al-Quran yang dapat dijadikan sandaran dalam berinvestasi, antara lain Q.S. Al-Hasyr ayat 18 yang berbunyi:

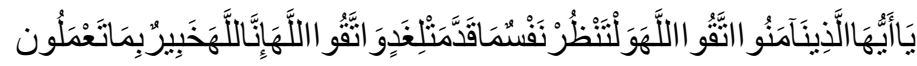

Artinya :"Wahai orang-orang yang beriman! Bertaqwalahkepada Allah dan hendaklahsetiap orang memperhatikan apa yang telah diperbuatnya untuk hari esok (akhirat), dan bertaqwalah kepada Allah. Sungguh Allah Maha Teliti terhadap apa yang kamu kerjakan”. (QS. Al-Hasyr : 18) (Departemen Agama RI, 2010).

\section{Prinsip-prinsip Investasi}

Dalam berinvestasi ditentukan bukan pada faktor bunga, melainkan pada ketentuan tingkat harga dan keberhasilannya dalam berinvestasi. Investasi dalam Islam memiliki 4 (empat) prinsip utama yaitu (Suharto, 2015):

1. Halal

2. Berkah

3. Bertambah

4. Realistis

\section{Gambar 1.Kerangka Berpikir}

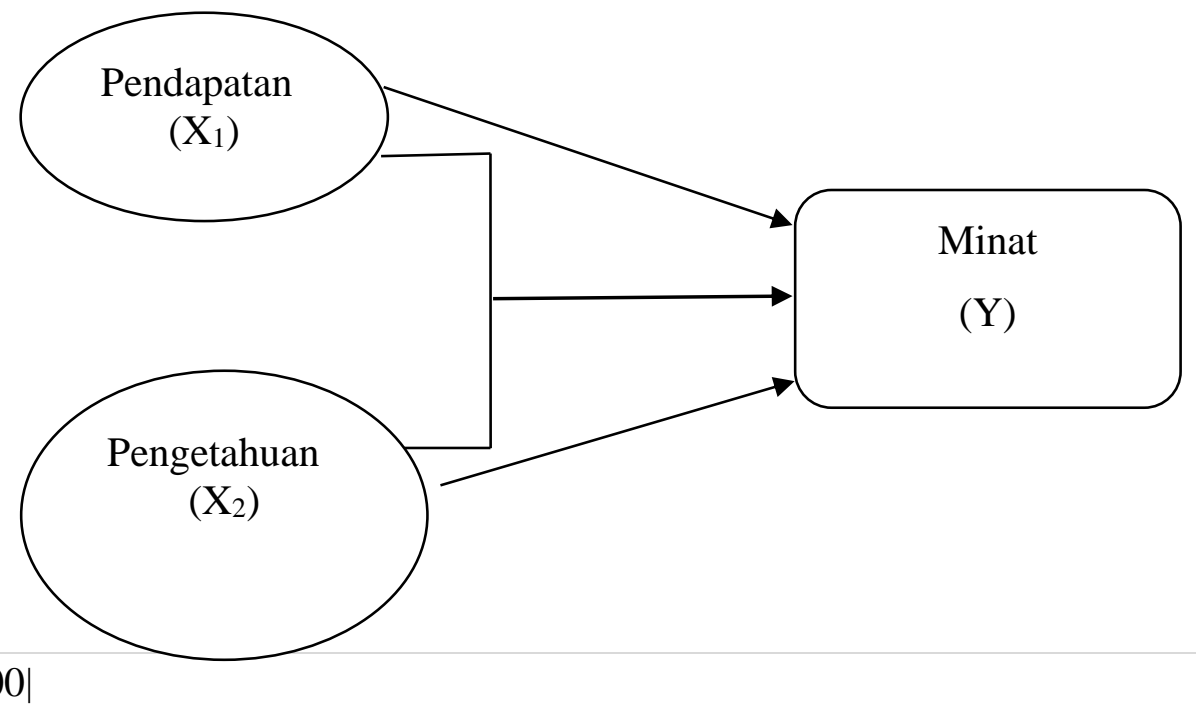


$\mathrm{H}_{0}$ : Pendapatan tidak berpengaruh terhadap minat calon nasabah berinvestasi di Pegadaian Syariah.

$\mathrm{H}_{1}$ : Pendapatan berpengaruh terhadap minat calon nasabah berinvestasi di Pegadaian Syariah.

$\mathrm{H}_{0}$ : Pengetahuan tidak berpengaruh terhadap minat calon nasabah berinvestasi di Pegadaian Syariah.

$\mathrm{H}_{2}$ : Pengetahuan berpengaruh terhadap minat calon nasabah berinvestasi di Pegadaian Syariah.

$\mathrm{H}_{0}$ : Pendapatan dan Pengetahuan tidak berpengaruh secara simultan terhadap minat calon nasabah berinvestasi di Pegadaian Syariah.

$\mathrm{H}_{3}$ : Pendapatan dan Pengetahuan berpengaruh secara simultan terhadap minat calon nasabah berinvestasi di Pegadaian Syariah.

\section{METODE}

Penelitian ini merupakan jenis penelitian kuantitatif. Dengan menggunakan metode survei dalam mengumpulkan data yang diperlukan.

\section{Populasi}

Adapun populasi dalam penelitian ini adalah seluruh nasabah di pegadaian syariah Cabang Kota Langsa yang berjumlah 11.167 nasabah, kecuali nasabah tabungan emas.

\section{Sampel}

Adapun teknik pengambilan sampel pada penelitian ini dilakukan melalui probability sampling dengan simple random sampling. Dalam penelitian ini yang menjadi sample adalah berjumlah 99 sample.

\section{Teknik Pengumpulan Data}

Teknik pengumpulan data yang digunakan dalam penelitian ini yaitu sebagai berikut:

1. Angkat (kuesioner); teknik pengumpulan data yang dilakukan dengan cara memberi atau menyebarkan daftar pertanyaan kepada responden untuk dijawab dengan harapan memberikan respon terhadap daftar pertanyaan tersebut(Umar, 2016).

2. Wawancara (Interview); digunakan sebagai teknik pengumpulan data, jika peneliti ingin melakukan studi pendahuluan untuk menemukan permasalahn yang harus 

Analisis Pengaruh Pendapatan Dan Pengetahuan Terhadap Minat Calon Nasabah Berinvestasi Emas...

diteliti, dan juga apabila peneliti ingin mengetahui hal-hal dari responden yang lebih mendalam (Sugiyono, 2017)

3. Dokumetasi :Dokumentsi yaitu teknik pengumpulan data dengan mempelajari catatan-catatan mengenai data pribadi responden, seperti yang dilakukan oleh seorang psikolog dalam meneliti perkembangan klien melalui catatan pribadinya (Fathoni, 2011). Metode dokumentasi dilakukan dengan cara mengambil data dari pegawai Pegadaian Syariah Kota Langsa, website Pegadaian Syariah dan berbagai data tentang Pegadaian Syariah Kota Langsa.

\section{Uji Validitas dan Reliabilitas}

a. Uji Validitas

Uji validitas digunakan untuk menguji seberapa baik kuesioner yangdibangun untuk mengukur suatu konsep adalah benar-benar dapat mengukurkonsep tersebut (Suhartanto, 2014)

b. Uji Reliabilitas

Reliabilitas adalah alat untuk mengukur suatu kuesioner yang merupakan indikator dari variabel. Suatu kuesioner dikatakan reliabel atau handal jika jawaban seseorang terhadap pernyataan adalah konsisten atau stabil dari waktu ke waktu (Ghozali, 2013)

\section{Uji Asumsi Klasik}

Uji Asumsi klasik yang digunakan mencakup :
a. Uji Normalitas
b. Uji Linearitas
c. Uji Multikolinieritas
d. Uji Heteroskedastisitas
e. Uji Autokorelasi

\section{Analisis Regresi Berganda}

Analisis regresi berganda dilakukan untuk mengetahui pengaruh antara dua atau lebih variabel independen dengan satu variabel dependen. Analisis regresi berganda digunakan dalam penelitian karena variabel independen lebih dari satu variabel (Priyatno, 2014).Adapun Persamaanregresi berganda pada penelitian ini adalah sebagai berikut: 


$$
\mathrm{Y}=\alpha+\mathrm{b} 1 \mathrm{X} 1+\mathrm{b} 2 \mathrm{X} 2+\mathrm{e}
$$

Keterangan :

Y : Minat Calon Nasabah

a : Konstanta

b1 : Koefisien Regresi Pendapatan

X1 : Pendapatan

b2 : Koefisien Regresi Pengetahuan

X2 : Pengetahuan

e $:$ Error $^{1}$

\section{Uji Hipotesis}

a. Uji $\mathrm{t}$

Uji $\mathrm{t}$ adalah pengujian yang dilakukan untuk melihat apakah variabel Independen secara parsial(individu) berpengaruh signifikan terhadapvariabel dependen dengan memberikan asumsi bahwa variabel lainnya konstant (Latan\&Temalagi, 2013).

b. Uji F

Uji $\mathrm{F}$ bertujuan untuk mengetahui apakah semua variabel independen yang dimasukkan dalam model regresi mempunyai pengaruh secara simultan (bersamasama) terhadap variabel dependen atau tidak (Latan\&Temalagi, 2013)

c. ji Koefisien Determinasi $\left(\mathrm{R}^{2}\right)$

Koefisien determinasi $\left(\mathrm{R}^{2}\right)$ digunakan untuk melihat seberapa besar kemampuan variabel independen dalam menerangkan variasi dependen. Nilai koefisien determinasi $\left(\mathrm{R}^{2}\right)$ adalah antara 0 dan 1 .

\section{HASIL DAN PEMBAHASAN}

\section{Uji Validitas}

Hasil uji validitas ditunjukkan untuk melihat seberapa baik kuesioner yang digunakan dalam penelitian. Sebuah item pernyataan kuesioner dapat dikatakan valid jika $\mathrm{r}$ hasil > $\mathrm{r}$ tabel. Nilai $\mathrm{r}$ hasil dapat dilihat dalam correlation pada program SPSS dan $\mathrm{r}$ tabel dapat dilihat pada tabel producy moment. Dalam penelitian ini jumlah responden sebanyak 99 responden, maka besar $r$ tabel adalah 0,196. Adapun hasil uji validitas dalam

1 Imam Ghozali, AplikasiAnalisis Multivariate dengan Program IBM SPSS21. EdisiKeTujuh(Semarang; Badan Penerbit Universitas Diponegoro, 2013). h. 95. 

Analisis Pengaruh Pendapatan Dan Pengetahuan Terhadap Minat Calon Nasabah Berinvestasi Emas... penelitian ini yaitu sebagai berikut:

a. Variabel Pendapatan $\left(\mathrm{X}_{1}\right)$

Berdasarkan dari pengujian validitas untuk variabel pendapatan, maka diperoleh hasil sebagai berikut:

Tabel 1

Hasil Uji Validitas Pendapatan

\begin{tabular}{|c|c|c|c|}
\hline Pernyataan & $\mathrm{r}_{\text {hasil }}$ & $\mathrm{r}_{\text {tabel }}$ & Keterangan \\
\hline Pernyataan 1 & 0,684 & 0,196 & Valid \\
\hline Pernyataan 2 & 0,761 & 0,196 & Valid \\
\hline Pernyataan 3 & 0,770 & 0,196 & Valid \\
\hline Pernyataan 4 & 0,739 & 0,196 & Valid \\
\hline
\end{tabular}

Sumber: data primer yang diolah, 2021

Berdasarkan tabel 1 dapat diketahui bahwa semua hasil uji $r_{\text {hasil }}>r_{\text {tabel }}$ dengan ketentuan $r_{\text {tabel }}=0,196$. Sehingga dapat disimpulkan bahwa semua butir pertanyaan yang digunakan dalam variabel pendapatan adalah valid untuk dijadikan pengambilan keputusan.

a. Variabel Pengetahuan $\left(\mathrm{X}_{2}\right)$

Berdasarkan dari pengujian validitas untuk variabel pengetahuan, maka diperoleh hasil sebagai berikut:

Tabel 2

Hasil Uji Validitas Pengetahuan

\begin{tabular}{|c|c|c|c|}
\hline Pernyataan & $\mathrm{r}_{\text {hasil }}$ & $\mathrm{r}_{\text {tabel }}$ & Keterangan \\
\hline Pernyataan 1 & 0,646 & 0,196 & Valid \\
\hline Pernyataan 2 & 0,596 & 0,196 & Valid \\
\hline Pernyataan 3 & 0,885 & 0,196 & Valid \\
\hline Pernyataan 4 & 0,805 & 0,196 & Valid \\
\hline Pernyataan 5 & 0,868 & 0,196 & Valid \\
\hline
\end{tabular}

Sumber: data primer yang diolah, 2021

Berdasarkan tabel 2 dapat diketahui bahwa semua hasil uji $r_{\text {hasil }}>r_{\text {tabel }}$ dengan ketentuan $r_{\text {tabel }}=0,196$. Sehingga dapat disimpulkan bahwa semua butir pertanyaan yang digunakan dalam variabel pengetahuan adalah valid untuk dijadikan pengambilan keputusan. 
b. Variabel Minat Investasi Emas (Y)

Berdasarkan dari pengujian validitas untuk variabel minat investasi emas, maka diperoleh hasil sebagai berikut:

Tabel 3

Hasil Uji Validitas Minat tabungan emas

\begin{tabular}{|c|c|c|c|}
\hline Pernyataan & $\mathrm{R}_{\text {hasil }}$ & $\mathrm{r}_{\text {tabel }}$ & Keterangan \\
\hline Pernyataan 1 & 0,878 & 0,196 & Valid \\
\hline Pernyataan 2 & 0,902 & 0,196 & Valid \\
\hline Pernyataan 3 & 0,812 & 0,196 & Valid \\
\hline Pernyataan 4 & 0,605 & 0,196 & Valid \\
\hline Pernyataan 5 & 0,900 & 0,196 & Valid \\
\hline
\end{tabular}

Sumber: data primer yang diolah, 2021

Berdasarkan tabel 3, dapat diketahui bahwa semua hasil uji $r_{\text {hasil }}>r_{\text {tabel }}$ dengan ketentuan $r_{\text {tabel }}=0,196$. Sehingga dapat disimpulkan bahwa semua butir pertanyaan yang digunakan dalam variabel minat berinvestasi emas adalah valid untuk dijadikan pengambilan keputusan.

\section{Uji Reliabilitas}

Selain melakukan uji validitas dari tiap-tiap varibel pendapatan, pengetahuan dan minat berinvestasi emas maka, selanjutnya dapat dilakukan uji realibilitas. Hasil analisis reliabilitas dapat dilihat pada program SPSS dan ditunjukkan dengan besarnya nilai alpa. Kuesioner dikatakan reliabel jika nilai Cronbach's Alpa $>0.60$ maka, kuesioner tersebut memiliki reliabilitas yang baik. Hasil uji reliabilitas yang diperoleh dalam penelitian ini yaitu sebagai berikut:

\section{Tabel 4}

Hasil Uji Reliabilitas

\begin{tabular}{|c|c|c|c|}
\hline Variabel & $\begin{array}{c}\text { Crobach's } \\
\text { Alpha }\end{array}$ & $\begin{array}{c}\text { Standar } \\
\text { Min }\end{array}$ & Keterangan \\
\hline Pendapatan $\left(\mathrm{X}_{1}\right)$ & 0.792 & 0.60 & Reliabel \\
\hline Pengetahuan $\left(\mathrm{X}_{2}\right)$ & 0.798 & 0.60 & Reliabel \\
\hline Minat Berinvestasi Emas $(\mathrm{Y})$ & 0.811 & 0.60 & Reliabel \\
\hline
\end{tabular}

Sumber: data primer yang diolah, 2021

Berdasarkan tabel 4 terlihat semua variabel memiliki Crobach's Alpha> 0.60. Dengan demikian dapat disimpulkan bahwa variabel pendapatan, pengetahuan dan minat berinvestasi emas adalah reliabel sehingga dapat digunakan sebagai alat ukur untuk 
penelitian selanjutnya.

\section{Uji Asumsi Klasik}

a. Uji Normalitas

Pengujian normalitas dilakukan untuk melihat apakah dalam model regresi, variabel dependen dan independen memiliki distribusi normal atau tidak (Juliandi\& Irfan, 2013)Adapun hasil uji normalitas adalah sebagai berikut:

Gambar 2

Hasil Uji Normalitas

\section{Normal P.P Plot of Regression Standardized Residual}

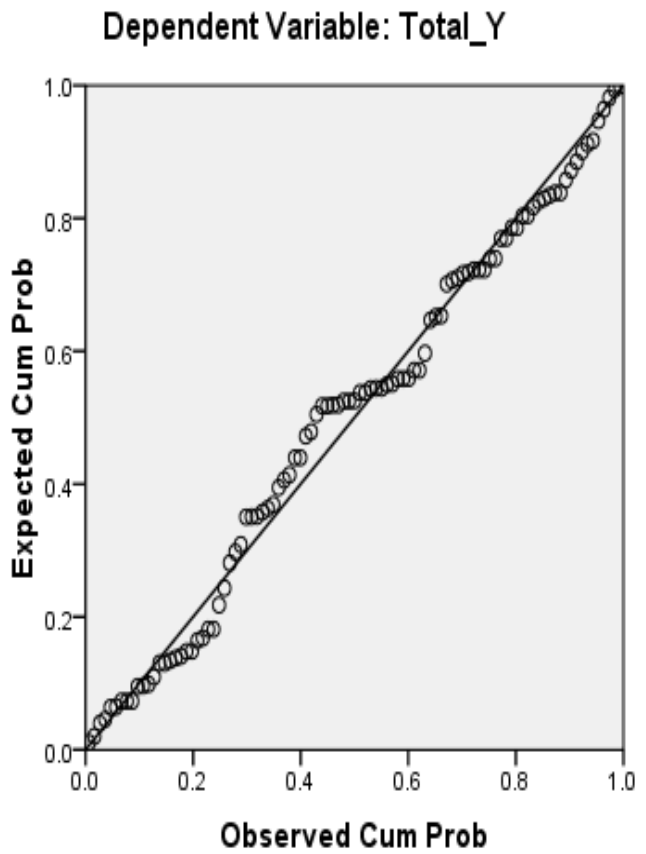

Sumber: data primer yang diolah, 2021

Dari gambar 2 diatas tampak titik - titik menyebar disekitar garis diagonal dan mengikuti arah garis diagonal, maka dapat disimpulkan bahwa uji normalitas dapat terpenuhi. Dengan demikian data dalam penelitian ini memiliki distribusi normal. 


\section{Gambar 3 \\ Histogram}

Histogram

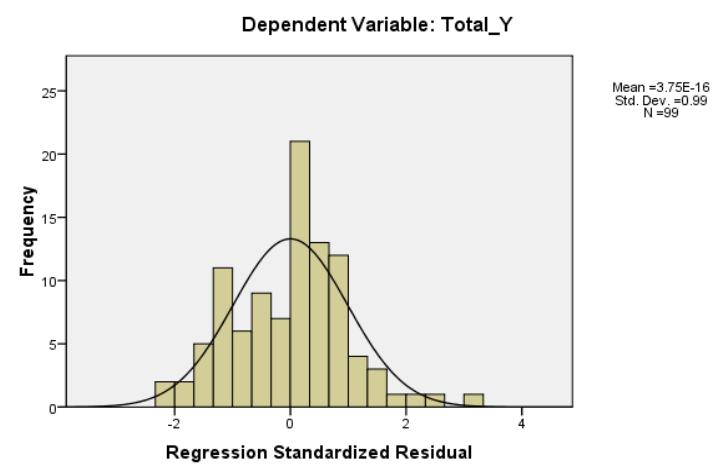

Sumber: data primer yang diolah, 2021

Dari hasil gambar diatas dapat dilihat pada grafik histogram bahwa pada pola grafik histogram menunjukkan pola berdistribusi normal. Sehingga dapat disimpulkan bahwa data dalam penelitian ini berdistribusi normal.

Tabel 5

\section{Kolmogrov-Smirnov}

One-Sample Kolmogorov-Smirnov Test

\begin{tabular}{|ll|r|}
\hline & & Unstandardized Residual \\
\hline Normal Parameters ${ }^{\mathrm{a}}$ & Mean & 99 \\
& Std. Deviation & .0000000 \\
Most Extreme Differences & Absolute & 2.60764918 \\
& Positive & .083 \\
& Negative & .064 \\
Kolmogorov-Smirnov Z & & -.083 \\
Asymp. Sig. (2-tailed) & & .830 \\
\hline
\end{tabular}

a. Test distribution is Normal.

Sumber: data primer yang diolah, 2021

Berdasarkan hasil dari tabel Kolmogrov-Smirnov menunjukkan bahwa nilai Kolmogrov-Smirnov yaitu 0,830 dan sinifikan pada 0,496 nilai tersebut lebih besar dari taraf signifikan 0,05. Hal ini menunjukkan bahwa data berdistribusi normal. Sehingga dapat disimpulkan bahwa data dalam penelitian ini berdistribusi normal dan pada model regresi memenuhi asumsi normalitas.

b. Uji Linearitas

Uji linearitas digunakan untuk melihat apakah model garis linear yang ditetapkan 
sesuai dengan keadaannya atau tidak. Dalam hal ini uji linearitas dilakukan dengan menggunakan analisis tabel ANOVA. Kriteria yang ditetapkan untuk menentukan kelinearitasan garis regresi adalah nilai koefisien signifikan. Jika koefisien signifikan >alpha yang ditentukan yaitu 5\%, maka dapat dikatakan bahwa garis regresi berbentuk linear ( Santoso, 2010). Adapun hasil uji linearitas adalah sebagai berikut:

Tabel 6

\section{Hasil Uji Linearitas}

ANOVA Table

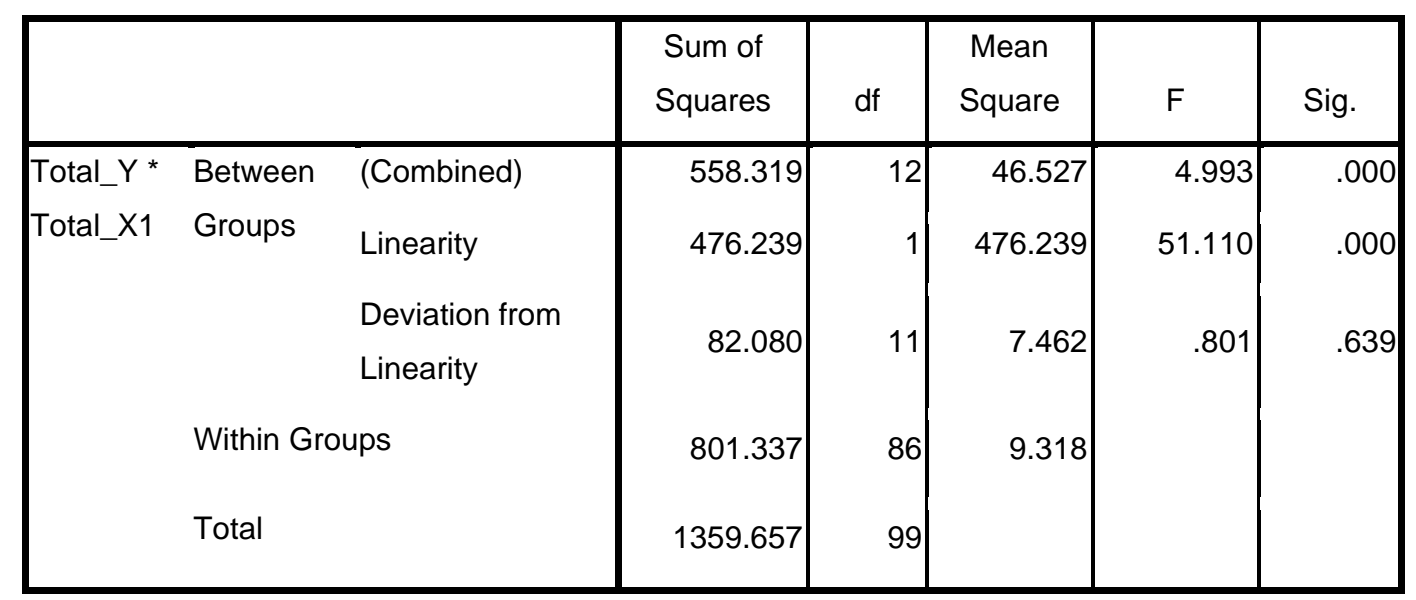

ANOVA Table

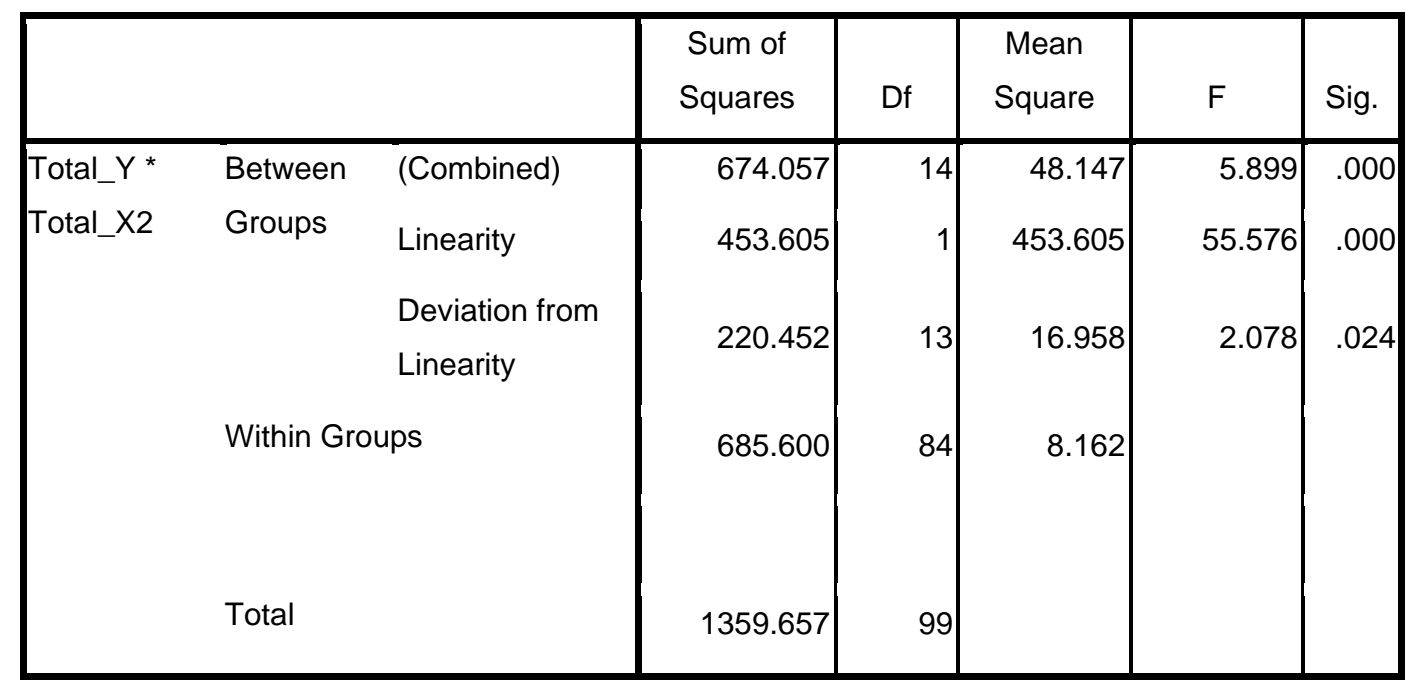

Sumber: data primer yang diolah, 2021

Berdasarkan tabel6 diatas, maka hasil uji linearitas menunjukkan nilai koefisien signifikan $X_{1}$ yaitu 0,639 . Hal ini menunjukkan bahwa $X_{1}$ memiliki hubungan linear antara variabel $\mathrm{X}_{1}$ dan variabel $\mathrm{Y}$, karena nilai signifikan linearity $<0,05$ dan pada deviation from linearity signifikansinya $>0.05$. Sedangkan nilai koefisien signifikan $X_{2}$ yaitu 0,024.Hal ini menunjukkan bahwa $\mathrm{X}_{2}$ memiliki hubungan linear antara variabel $\mathrm{X}_{2}$ 108 
dan variabel Y. Akan tetapi, adanya pola linear pada deviasi atau eror, karena nilai signifikan linearity $<0,05$ dan pada deviation from linearity signifikansinya $<0.05$.

Sehingga dapat disimpulkan bahwa dari hasil tabel diatas adalah variabel $\mathrm{X}_{1}$ (Pendapatan) memenuhi persyaratan linearitas, sedangkan pada variabel $\mathrm{X}_{2}$ (Pengetahuan) tidak memenuhi persyaratan linearitas.

c. Uji Multikolinieritas

Uji multikolinieritas dilakukan untuk menguji apakah model regresi ditemukan adanya korelasi antar variabel bebas (independen) (Ghozali,2013) Cara yang dilakukan untuk melihat nilai uji multikolinieritas adalah dengan melihat nilai VIF (Variance Inflasi Factor) yang berada disekitar angka 1 atau VIF $<10$ dan nilai Tolerance mendekati angka 1 (Umar, 2016). Hasil uji multikolinearitas adalah sebagai berikut:

Tabel 7

Hasil Uji Multikolinearitas

Coefficients $^{\mathrm{a}}$

\begin{tabular}{|l|r|r|r|r|r|}
\hline \multirow{2}{*}{ Model } & \multicolumn{2}{|c|}{$\begin{array}{c}\text { Unstandardized } \\
\text { Coefficients }\end{array}$} & $\begin{array}{c}\text { Standardized } \\
\text { Coefficients }\end{array}$ & \multicolumn{2}{|c|}{ Collinearity Statistics } \\
\cline { 2 - 7 } & \multicolumn{1}{|c|}{ B } & Std. Error & Beta & Tolerance & VIF \\
\hline 1 (Constant) & 1.695 & 1.720 & & & .883 \\
Pendapatan & .564 & .096 & .447 & .883 & 1.132 \\
Pengetahuan & .480 & .086 & .425 & .883 \\
\hline
\end{tabular}

Sumber: data primer yang diolah, 2021

Dari tabel 7 diatas terlihat nilai VIF (Variance Inflation Factor) bahwa kedua variabel $<10$. Sehingga dapat disimpulkan dalam model model regresi tidak terjadi gejala multikolinieritas.

d. Uji Heteroskedastisitas

Uji heteroskedastisitas bertujuan menguji apakah dalam model regresi terjadi ketidaksamaan variance dari residual satu pengamatan ke pengamatan yang lain (Ghozali, 2013) Dasar pengambilan keputusan yaitu jika suatu pola tertentu, seperti titik-titik yang ada membentuk suatu pola tertentu yang teratur, maka terjadi heteroskedastisitas. Jika tidak ada pola yang jelas serta titik-titik menyebar dibawah dan diatas angka 0 pada sumbu $\mathrm{Y}$, maka tidak terjadi heteroskedastisitasa (Juliandi \& Irfan,2013). Hasil uji heteroskedastisitas adalah sebagai berikut: 


\section{Gambar 4}

\section{Hasil Uji Heteroskedastisitas}

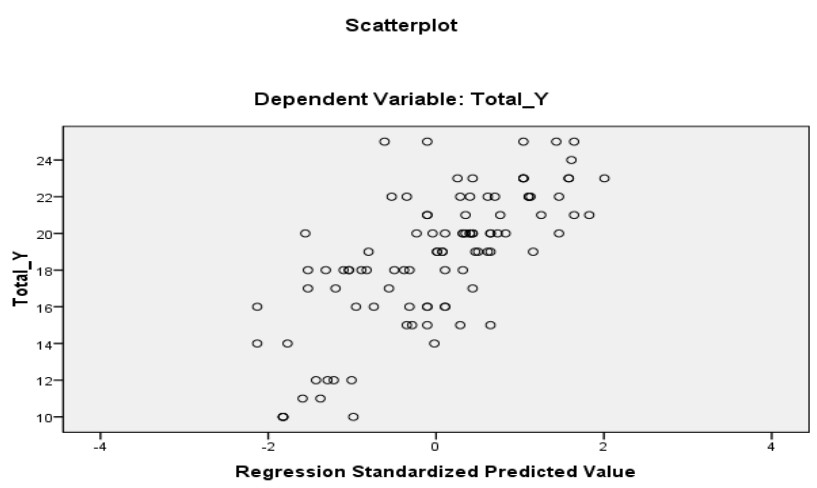

Sumber: data primer yang diolah, 2021

Berdasarkan hasil uji heteroskedastisitas terlihat pada gambar 4.3 diatas bahwa hasilnya menggambarkan sebaran titik - titik yang menyebar secara acak dan tidak membentuk pola tertentu. Kemudian, titik - titik data menyebar diatas angka 0 pada sumbu Y. Sehingga dapat disimpulkan dari hasil pengamatan regresi linear pada penelitian ini tidak terjadi kendala heteroskedastisitas.

e. Uji Autokorelasi

Uji autokorelasi diuiji untuk mengetahui apakah dalam sebuah model regresi linear ada korelasi antara kesalahan pengganggu pada periode ke t dengan kesalahan pada periode t-1 (sebelumnya). Model regresi yang baik adalah bebas dari autokorelasi (Juliandi \& Irfan,2013).

Adapun cara mengidentifikasi uji autokorelasi yaitu dengan melihat nilai Durbin Watson (D-W) (Juliandi \& Irfan,2013) :.

1. Terjadi autokorelasi positif, jika nilai D-W dibawah -2.

2. Tidak terjadi autokorelasi, jika nilai $\mathrm{D}-\mathrm{W}$ berada diantara -2 dan +2 .

3. Terjadi autokorelasi negatif, jika D-W di atas +2 .

Tabel 8

\section{Hasil Uji Autokorelasi}

Model Summary

\begin{tabular}{|c|c|c|c|c|c|c|}
\hline \multirow[b]{2}{*}{ Mode } & \multicolumn{5}{|c|}{ Change Statistics } & \multirow[b]{2}{*}{$\begin{array}{l}\text { Durbin- } \\
\text { Watson }\end{array}$} \\
\hline & $\begin{array}{c}\text { R Square } \\
\text { Change }\end{array}$ & $\begin{array}{c}\mathrm{F} \\
\text { Change }\end{array}$ & df1 & df2 & $\begin{array}{c}\text { Sig. F } \\
\text { Change }\end{array}$ & \\
\hline 1 & .510 & 49.937 & 2 & 96 & .000 & 1.860 \\
\hline
\end{tabular}




\begin{tabular}{|c|c|c|c|c|c|c|}
\hline \multirow[b]{2}{*}{ Mode } & \multicolumn{5}{|c|}{ Change Statistics } & \multirow[b]{2}{*}{$\begin{array}{l}\text { Durbin- } \\
\text { Watson }\end{array}$} \\
\hline & $\begin{array}{c}\text { R Square } \\
\text { Change }\end{array}$ & $\begin{array}{c}\mathrm{F} \\
\text { Change }\end{array}$ & df1 & df2 & $\begin{array}{l}\text { Sig. F } \\
\text { Change }\end{array}$ & \\
\hline 1 & .510 & 49.937 & 2 & 96 & .000 & 1.860 \\
\hline
\end{tabular}

Sumber: data primer yang diolah, 2021

Berdasarkan tabel 8 diatas dapat dilihat hasil analisis data menggunakan SPSS menunjukkan nilai Durbin Watson sebesar 1.860, maka dapat diketahui bahwa nilai D-W berada diantara -2 sampai +2 . Dengan demikian regresi dalam penelitian ini tidak ada autokorelasi.

\section{Analisis Regresi Berganda}

Analisis regresi berganda digunakan untuk mengetahui pengaruh antara dua atau lebih variabel independen yaitu variabel pendapatan $\left(\mathrm{X}_{1}\right)$ dan pengatahuan $\left(\mathrm{X}_{2}\right)$ dengan satu variabel dependen yaitu minat calon nasabah (Y). Analisis ini untuk mengetahui hubungan antara variabel independen dengan variabel dependen baik positif maupun negatif. (Priyatno, 2014).Adapun hasil uji analisis regresi berganda yaitu sebagai berikut:

\section{Tabel 9}

\section{Hasil Uji Regresi Berganda}

Coefficients $^{\mathrm{a}}$

\begin{tabular}{|c|c|c|c|c|c|c|c|}
\hline \multirow[b]{2}{*}{ Model } & \multicolumn{2}{|c|}{$\begin{array}{c}\text { Unstandardized } \\
\text { Coefficients }\end{array}$} & \multirow{2}{*}{$\begin{array}{c}\begin{array}{c}\text { Standardized } \\
\text { Coefficients }\end{array} \\
\text { Beta }\end{array}$} & \multirow[b]{2}{*}{$\mathrm{t}$} & \multirow[b]{2}{*}{ Sig. } & \multicolumn{2}{|c|}{ Collinearity Statistics } \\
\hline & $\mathrm{B}$ & Std. Error & & & & Tolerance & VIF \\
\hline $1 \quad$ (Constant) & 1.695 & 1.720 & & .985 & .327 & & \\
\hline Total_X1 & .564 & .096 & .447 & 5.876 & .000 & .883 & 1.132 \\
\hline Total_X2 & .480 & .086 & .425 & 5.592 & .000 & .883 & 1.132 \\
\hline
\end{tabular}

a. Dependent Variable: Total_Y

Sumber: data primer yang diolah, 2021

Persamaan regresi yang didapatkan dari hasil perhitungan tabel diatas adalah sebagai berikut: $\mathrm{Y}=1,695+0,564 \mathrm{X} 1+0,480 \mathrm{X} 2$

Keterangan:

$\mathrm{X}_{1}$ : Variabel Pendapatan

$\mathrm{X}_{2}$ : Variabel Pengetahuan

Y : Minat Calon Nasabah 
Berdasarkan persamaan regresi di atas maka dapat dijelskan sebagai berikut:

1. Dari persamaan koefisien regresi di atas, konstanta $(\alpha)$ adalah sebesar 1,695 menunjukkan apabila variabel pendapatan dan variabel pengetahuan bernilai nol (0), maka besarnya tingkat minat calon nasabah berinvestasi emas adalah sebesar 1,695 .

2. Berdasarkan persamaan regresi menunjukkan bahwa variabel pendapatan $\left(\mathrm{X}_{1}\right)$ mempunyai arah koefisien regresi positif dengan nilai koefisien sebesar 0,564. Artinya jika variabel pendapatan mengalami peningkatan sebesar 1 kali maka minat calon nasabah akan naik sebesar 0,564 dengan asumsi variabel lain konstan.

3. Berdasarkan persamaan regresi menunjukkan bahwa variabel pengetahuan $\left(\mathrm{X}_{2}\right)$ mempunyai arah koefisien regresi positif dengan nilai koefisien sebesar 0,480. Artinya jika variabel pengetahuan mengalami peningkatan sebesar 1 kali maka minat calon nasabah akan naik sebesar 0,480 dengan asumsi variabel lain konstan.

\section{Uji Hipotesis}

Uji hipotesis digunakan untuk menganalisis apakah hipotesis diterima maupun ditolak, maka dapat dilihat dari nilai probabilitasnya dengan melihat kriteria penerimaan maupun penolakan hipotesis. Uji hipotesis menggunakan uji t dan uji F yaitu sebagai berikut ( Anton, 2006)

a. $\quad$ Uji t (Parsial)

Uji t dilakukan untuk melihat apakah pengaruh pendapatan dan pengetahuan terhadap minat calon nasabah berinvestasi emas dipegadaian Syariah Kota Langsa secara parsial (individu).

Adapun hasil dari uji t dan uji hipotesis dapat dilihat pada tabel sebagai berikut:

Tabel 10

Hasil Uji t

Coefficients $^{\mathrm{a}}$

\begin{tabular}{|l|r|r|r|r|r|}
\hline \multirow{2}{*}{ Model } & \multicolumn{2}{|c|}{$\begin{array}{c}\text { Unstandardized } \\
\text { Coefficients }\end{array}$} & \multicolumn{1}{c|}{$\begin{array}{c}\text { Standardized } \\
\text { Coefficients }\end{array}$} & \multirow{2}{*}{ T } & \multicolumn{1}{c|}{ Sig. } \\
\cline { 2 - 4 } & \multicolumn{1}{|c|}{ B } & Std. Error & \multicolumn{1}{|c|}{ Beta } & \multicolumn{1}{c|}{ T } \\
\hline 1 (Constant) & 1.695 & 1.720 & & .985 & .327 \\
Total_X1 & .564 & .096 & .447 & 5.876 & .000 \\
Total_X2 & .480 & .086 & .425 & 5.592 & .000 \\
\hline
\end{tabular}




\section{Coefficients $^{\mathrm{a}}$}

\begin{tabular}{|c|c|c|c|c|c|}
\hline \multirow[b]{2}{*}{ Model } & \multicolumn{2}{|c|}{$\begin{array}{l}\text { Unstandardized } \\
\text { Coefficients }\end{array}$} & \multirow{2}{*}{$\begin{array}{c}\text { Standardized } \\
\text { Coefficients }\end{array}$} & \multirow[b]{2}{*}{$\mathrm{T}$} & \multirow[b]{2}{*}{ Sig. } \\
\hline & B & Std. Error & & & \\
\hline 1 (Constant) & 1.695 & 1.720 & & .985 & .327 \\
\hline Total_X1 & .564 & .096 & .447 & 5.876 & .000 \\
\hline Total X2 & .480 & .086 & .425 & 5.592 & .000 \\
\hline
\end{tabular}

a. Dependent Variable: Total_Y

Sumber: data primer yang diolah, 2021

1) Berdasarkan tabel 10, dapat dikatakan nilai probabilitas atau Sig. Dari variabel pendapatan adalah 0,000 lebih kecil dari tingkat signifikan yaitu 0,05, maka dapat disimpulkan bahwa pengaruh yang terjadi antara variabel pendapatan dengan minat calon nasabah berinvestasi emas di pegadaian Syariah Kota Langsa adalah signifikan. Jadi pendapatan berpengaruh terhadap Y sebesar 5,876 dan bersifat positif serta signifikan. Sehingga $\mathrm{H}_{1}$ diterima dan $\mathrm{H}_{0}$ ditolak.

2) Berdasarkan tabel 10, dapat dikatakan nilai probabilitas atau Sig. Dari variabel pendapatan adalah 0,000 lebih kecil dari tingkat signifikan yaitu 0,05, maka dapat disimpulkan bahwa pengaruh yang terjadi antara variabel pengetahuan dengan minat calon nasabah berinvestasi emas di pegadaian Syariah Kota Langsa adalah signifikan. Jadi pengetahuan berpengaruh terhadap Y sebesar 5,592 dan bersifat positif serta signifikan. Sehingga $\mathrm{H}_{2}$ diterima dan $\mathrm{H}_{0}$ ditolak.

\section{b. Uji F (Simultan)}

Uji F digunakan untuk menguji apakah terdapat pengaruh pendapatan dan pengetahuan terhadap minat calon nasabah berinvestasi emas dipegadaian Syariah Kota Langsa secara simultan (bersama - sama).Adapun hasil dari uji $\mathrm{F}$ dan uji hipotesis dapat dilihat pada tabel sebagai berikut:

\section{Tabel 11 \\ Hasil Uji F \\ ANOVA $^{b}$}

\begin{tabular}{|rr|r|r|r|r|r|}
\hline Model & Sum of Squares & Df & Mean Square & F & Sig. \\
\hline 1 & Regression & 693.273 & 2 & 346.636 & 49.937 & $.000^{\mathrm{a}}$ \\
Residual & 666.384 & 96 & 6.941 & & \\
Total & 1359.657 & 98 & & & \\
\hline
\end{tabular}

a. Predictors: (Constant), Pendapatan, Pengetahuan

b. Dependent Variable: Minat Calon Nasabah

Sumber: data primer yang diolah, 2021 
Dari tabel di atas terlihat bahwa variabel independen (pendapatan dan pengetahuan) mempunyai nilai probabilitas atau signifikan sebesar 0,000 lebih kecil dari tingkat signifikan yaitu 0,05 (Sig. 0,000 < 0,05). Dengan demikianberdasarkan hasil analisis diatas dapat disimpulkan bahwa data dalam penelitian ini adalah bersifat positif serta signifikan. Sehingga variabel independen (pendapatan dan pengetahuan) memberikan pengaruh simultan terhadap variabel dependen yaitu minat calon nasabah berinvestasi emas di Pegadaian Syariah Kota Langsa. Hal ini menunjukkan bahwa $\mathrm{H}_{3}$ diterima dan $\mathrm{H}_{0}$ ditolak.

c. Uji Koefisien Determinasi $\left(\mathrm{R}^{2}\right)$

Koefisien determinasi $\left(\mathrm{R}^{2}\right)$ digunakan untuk melihat bagaimana variasi nilai variabel dependen (terikat) dipengaruhi oleh variasi nilai variabel independen (bebas). Adapun hasil uji koefisien determinasi $\mathrm{R}^{2}$ dapat dilihat pada tabel sebagai berikut:

Tabel 12

Hasil Uji Koefisien Determinasi $\mathbf{R}^{2}$

Model Summary

\begin{tabular}{l|r|r|r|r|}
\hline Model & $\mathrm{R}$ & R Square & $\begin{array}{c}\text { Adjusted R } \\
\text { Square }\end{array}$ & $\begin{array}{c}\text { Std. Error of the } \\
\text { Estimate }\end{array}$ \\
\hline 1 & $.714^{\mathrm{a}}$ & .510 & .500 & 2.635 \\
\hline
\end{tabular}
a. Predictors: (Constant), Pendapatan, Pengetahuan
b. Dependent Variable: Minat Calon Nasabah

Sumber: data primer yang diolah, 2021

Berdasarkan hasil uji determinasi yang dapat dilihat pada tabel $R$ Squarepada model Model Summary di atas, dari hasil uji tersebut didapatkan nilai $R$ Squaresebesar 0,510. Hal ini menunjukkan bahwa 51\% variabel minat calon nasabah dapat dijelaskan oleh variabel pendapatan dan pengetahuan, sedangkan sisanya (100\% - 51\%) adalah $49 \%$ dijelaskan oleh variabel lain yang tidak digunakan dalam penelitian ini.

\section{HASIL DAN PEMBAHASAN}

\section{Pendapatan berpengaruh terhadap minat calon nasabah berinvestasi emas di Pegadaian Kota Langsa}

Berdasarkan hasil uji t (secara parsial) pada variabel pendapatan $\left(\mathrm{X}_{1}\right)$ terhadap Y yaitu minat calon nasabah memperlihatkanjika nilai probabilitas $\leq$ taraf signifikan sebesar 0.05 $(0.000 \leq 0,05)$. Sehingga hipotesis $\mathrm{H}_{1}$ yang menyatakan: "Pendapatan berpengaruh terhadap minat calon nasabah berinvestasi emas di Pegadaian Syariah Kota Langsa", 114 
terbukti kebenarannya. Hal ini menunjukkan bahwa $\mathrm{H}_{1}$ diterima $\mathrm{H}_{0}$ ditolak. Dengan demikian dapat disimpulkan bahwa pendapatan berpengaruh positif dan signifikan terhadap minat calon nasabah berinvestasi emas di Pegadaian Syariah Kota Langsa.

Pendapatan adalah penghasilan atau gaji yang diperoleh oleh seseorang dalam jangka waktu tertentu sebagai balas jasa terhadap tenaga atau fikiran yang mereka sumbangkang. Semakin tinggi pendapatan yang diperoleh maka semakin besar pengeluaran atau kegiatan-kegiatan yang akan dilakukan. Sehingga dapat mendorong minat masyarakat untuk melakukan kegiatan tertentu seperti berinvestasi.

Dari hasil penelitian ini pendapatan berpengaruh terhadap minat calon nasabah berinvestasi emas di Pegadaian Syariah Kota Langsa. Hal ini terjadi dikarenakan jika pendapatan calon nasabah tinggi maka akan mendorong minat calon nasabah untuk berinvestasi emas yaitu pada produk tabungan emas di Pegadaian Syariah Kota Langsa.

\section{Pengetahuanberpengaruh terhadap minat calon nasabah berinvestasi emas di Pegadaian Kota Langsa}

Berdasarkan hasil uji t (secara parsial) pada variabel pengetahuan $\left(\mathrm{X}_{2}\right)$ terhadap $\mathrm{Y}$ yaitu minat calon nasabah memperlihatkan jika jika nilai probabilitas $\leq$ taraf signifikan sebesar $0.05(0.000 \leq 0,05)$. Sehingga hipotesis $\mathrm{H}_{2}$ yang menyatakan: "Pengetahuan berpengaruh terhadap minat calon nasabah berinvestasi emas di Pegadaian Syariah Kota Langsa", terbukti kebenarannya. Hal ini menunjukkan bahwa $\mathrm{H}_{2}$ diterima $\mathrm{H}_{0}$ ditolak. Dengan demikian dapat disimpulkan bahwa pengetahuan berpengaruh positif dan signifikan terhadap minat calon nasabah berinvestasi emas di Pegadaian Syariah Kota Langsa.

Pengetahuan adalah segala sesuatu yang diketahui oleh seseorang yang diperoleh melalui informasi yang didapatkan, baik informasi yang ditemukan oleh diri sendiri atau informasi yang didapatkan dari orang lain. Maka semakin banyak pengetahuan yang dimiliki oleh calon nasabah dan mereka paham terhadap investasi pada produk tabungan emas maka semakin tinggi minat masyarakat untuk mau melakukan investasi di Pegadaian Syariah Kota Langsa.

\section{Pendapatan dan Pengetahuanberpengaruh terhadap minat calon nasabah berinvestasi emas di Pegadaian Kota Langsa}

Berdasarkan hasil uji F (secara simultan) dapat disimpulkan bahwa hasil variabel pendapatan dan pengetahuan terhadap minat calon nasabah, jika nilai probabilitas $\leq$ taraf 
signifikan sebesar $0.05(0.000 \leq 0,05)$. Sehingga hipotesis $\mathrm{H}_{3}$ yang menyatakan: "Pendapatan dan Pengetahuan berpengaruh terhadap minat calon nasabah berinvestasi emas di Pegadaian Syariah Kota Langsa”, terbukti kebenarannya. Hal ini menunjukkan bahwa $\mathrm{H}_{3}$ diterima $\mathrm{H}_{0}$ ditolak. Berarti pendapatan dan pengetahuan berpengaruh signifikan secara simultan terhadap minat calon nasabah.

Dari hasil penelitian ini menunjukkan bahwa Pendapatan dan Pengetahuan berpengaruh terhadap minat calon nasabah berinvestasi emas di Pegadaian Syariah Kota Langsa. Hal ini terjadi karena pendapatan dan pengetahuan saling berkaitan dan memiliki pengaruh untuk mendorong minat calon nasabah dalam berinvestasi emas di Pegadaian Syariah Kota Langsa. Dengan demikian, calon nasabah yang memiliki pengetahuan yang lebih banyak dan memiliki pendapatan yang tinggi akan lebih tertarik untuk mau melakukan investasi emas yaitu pada produk tabungan emas. Jika pengetahuan lebih banyak dan pendapatan rendah maka kemungkinan kurangnya minat calon nasabah untuk berinvestasi emasdi Pegadaian Syariah Kota Langsa, sehingga mereka lebih mementingkan untuk memenuhi kebutuhan pokok mereka.

\section{KESIMPULAN}

Untuk variabel pendapatan secara parsial berpengaruh positif dan signifikan (dengan nilai signifikasinya $0,000<0,05$ ) terhadap minat calon nasabah berinvestasi emas di Pegadaian Syariah Kota Langsa. Begitu juga dengan variabel pengetahuan dimana secara parsial berpengaruh positif dan signifikan (dengan nilai signifikasinya $0,000<$ 0,05) terhadap minat calon nasabah berinvestasi emas di Pegadaian Syariah Kota Langsa. Secara simultan variabel pendapatan dan variabel pengetahuan berpengaruh positif dan signifikan (dengan nilai signifikasinya $0,000<0,05$ ) terhadap minat calon nasabah berinvestasi emas di Pegadaian Syariah Kota Langsa.

Berdasarkan uji determinasi menunjukkan bahwa nilai $R$-Square sebesar 0,510 atau $51 \%$. Hal ini menunjukkan bahwa presentase yang dipengaruhi oleh variabel pendapatan dan variabel pengetahuan terhadap minat calon nasabah berinvestasi emas di Pegadaian Syariah Kota Langsa sebesar 51\%, sedangkan sisanya sebesar 49\% dipengaruhi oleh variabel lain yang tidak termasuk pada model regresi. 


\section{PUSTAKA ACUAN}

Adisasmito, R. (2015).Analisis Kebijakan Publik. Yokyakarta: Grahallmu.

A. Karim, A. (2016). Bank Islam Analisis Fiqih dan Keuangan. Jakarta: PT Raja GrafindoPersada.

Aziz, A. (2010). Manajemen Investasi Syariah. Bandung: Alfabeta.

Azuar, J, Irfan. (2013). Metodologi Penelitian Kuantitatif. Medan: Perdana Mulya Saran.

Departemen Agama RI. (2010). Al-Qur'an Dan Terjemahnya. Bandung: CV Penerbit Diponegoro.

Dewan Syariah Nasional. (2021). Jual Beli Emas Secara tidak Tunai. Sumber: https://dsnmui.or.id/kategori/fatwa/page/5_Diunduh tanggal 30 Mei 2021.

Dwi, P. (2014). SPSS 22: Pengolahan Data Terpraktis. Yogyakarta: Andi Offset, 2014.

Fathoni, A. (2011). Metodologi Penelitian \& Teknik Penyusunan Skripsi. Jakarta: Rineka Cipta.

Frento t. S. (2015). Harga Emas Naik atauTurun Kita TetapUntung. Jakarta: PT. Elex Media Komput indo kompas Gramedia.

Ghozali, I. (2013). Aplikasi Analisis Multivariate dengan Program IBM SPSS 21. Edisi Ke Tujuh. Semarang; Badan Penerbit Universitas Diponegoro.

Hayati, M. (2016). Investasi Menurut Persepektif Ekonomi Islam, dalam Jurnal Ekonomi dan Bisnis Islam, Vol. 1, No. 1, 66-67.

Husein, U. (2016.) Metode Penelitian untuk Skripsi dan Tesis Bisnis. Jakarta: PT Raja Grafindo Persada.

Kuncoro, M. (2011). Metode Kuantitatif, Teori dan Aplikasi untuk Bisnis dan Ekonomi. Jogjakarta: UPP AMP YKPN.

Latan, H, Temalagi S. (2013). Analisis Multivariate Teknik dan Aplikasi Menggunakan

Program IBM SPSS 20.0. Bandung: Alfabeta.

Moena, A.( 2016). Pengaruh Pendapatan dan Pendidikan Nasabah terhadap Minat Nasabah Investasi Emas di BSM KC warung Buncit, (Skripsi), UIN Syarif Hidayatullah Jakarta.

Nur, R, Afif dan Budi, H. (2016). AnalisisFaktor-Faktor Yang Mempengaruhi Minat Berwirausaha Pada Mahasiswa Program Studi Manajemen Fakultas Ekonomi Universitas Kediri dalam Jurnal Ekonomi. Vol. 1, No. 2, 155.

Puspitasari, N. (2018). Keuangan Islam Teori dan Praktik. Yogyakarta: UII-Press.

Sahroni. O., Yahya. (2021). MenabungEmas. http://www.republika.id. Diunduhtanggal 15 Maret 2021.

Santoso. (2010). StatistikMultivariatKonsep dan Aplikasidengan SPSS. Jakarta: PT. Elex Media Komputindo.

Sugiyono (2017). Metodologi Penelitian Bisnis Pendekatan Kuantitatif, Kualitatif, Kombinasi, dan R\&D. Bandung: Alfabeta, 2017

Suhartanto, D. (2014). Metode Riset Pemasaran. Bandung: Alfabeta.

Sutedi, A. (2011). Hukum Gadai Syariah. Bandung: Alfabeta, 2011.

Syarif, H,. Asroi. (2013). Manajemen Pendidikan Substansi dan Implementasi dalam Praktik Pendidikan di Indonesia. Tangerang: Pustaka Mandiri.

Ulfa KN, M. (2019). Analisis Kewenangan Gadai Syariah Menurut Peraturan Otoritas Jasa Keuangan Nomor 31/Pojk.05/2016 Tentang Usaha Pegadaian. Dalam Jurnal Hukum Bisnis Islam. Vol. 11, No. 2, 445-447. 